\title{
Space-Related Scientific and Technical Information in Current Media Discourse: Research Results
}

\author{
O. V. Smirnova ${ }^{a, *}$, G. V. Denisova ${ }^{b, * *}$, O. R. Alevizaki ${ }^{a, * * *}$, \\ D. S. Ilyichenko ${ }^{a, * * * *}$, and A. S. Antipova ${ }^{b, * * * * *}$ \\ ${ }^{a}$ Faculty of Journalism, Lomonosov Moscow State University, Moscow, 125009 Russia \\ ${ }^{b}$ Faculty of Psychology, Lomonosov Moscow State University, Moscow, 125009 Russia \\ *e-mail: smirnovaorama@gmail.com \\ **e-mail: g.v.denissova@gmail.com \\ ***e-mail:olgafl@yandex.ru \\ ****e-mail: ilchenkod@yandex.ru \\ *****e-mail: antipovaaline@gmail.com
}

Received March 27, 2021

\begin{abstract}
By informing mass audience about scientific, engineering, and technological achievements, modern media contribute to the growth of the prestige of scientific and innovative activities and increase society's susceptibility to scientific and technological progress and innovations. One of the priorities for scientific and technological development in the Russian Federation is the study and exploration of outer space. Mass media can be an effective tool for popularizing fundamental and applied space research and its impact on everyday life, thereby updating the image of space in mass consciousness and society's representations of the present and the future. The leading federal socio-political newspapers Komsomolskaya Pravda, Rossiyskaya Gazeta, and Kommersant, as well as the online media Lenta.Ru and Gazeta.Ru, were selected as the object of this study. The research period covered January-December 2020. Publications related to space were selected and analyzed using Integrum, the information retrieval system for monitoring and analyzing the media, and the word2vec algorithm based on artificial neural networks. The original methodology made it possible to determine the ratio of publications about space in the total amount of mass media reports and to identify key topical areas of the space information agenda and features of its geography.
\end{abstract}

Keywords: space, scientific and technical information, information agenda, modern media discourse DOI: $10.3103 / \mathrm{S} 0147688221020118$

\section{INTRODUCTION}

The intellectual potential of modern Russian society is continuously enriched with innovations; meanwhile, it is necessary to consider the fact that intelligence must be converted into a product of both a material and moral nature: this is one of the important manifestations of the principle of the unity of consciousness and activity. The media space as a structural entity should provide optimal information interaction and influence society by creating a picture of the world that is continuously updated in the consciousness of a person, as well as by subsequently transforming potential information into real information and thereby optimizing the intellectual culture of a person [1].

The media play an increasingly important role in the social construction processes based on dynamic information exchange, which are synchronous with the production dynamics of scientific and technical information. It should be noted that science, as the most important social institution in the context of current digitalization processes, is intensively mediatized and undergoes dramatic changes, just like other public spheres [2,3]. In particular, researchers emphasize the insufficiency of current interactions between fundamental science and industry and the key role of information exchange as a determining factor in the model of innovative development of Russia's economy [4, 5].

Thus, it can be argued that "mediatizing" science is becoming an important component of the constantly expanding object field of media research [6-8]. It is also important to note that the continuous interaction of media channels, media content, its producers, as well as consumers and audiences in the digital space leads, among other things, to "interaction of social and individual phenomena in the media environment, thus affecting social and individual life" [9]. Let us emphasize once again that this greatly increases the responsibility of journalism and media in realizing the role of information for the scientific and technological 
development of society. The problems of popularizing science and maintaining the prestige of scientific and technical professions have become one of the main national priorities of the global powers. As a measure to activate innovative processes in the national economy and social sphere, the Strategy for Innovative Development of the Russian Federation for the period up to 2020 "Innovative Russia-2020" points out the importance of strengthening "the promotion of scientific knowledge and scientific-technical and innovative activities in the media" [10]. Modern researchers note the effectiveness of using the media as a channel for disseminating information that can affect the socio-economic development of society and the formation of public opinion about science, technology, and innovation [11-13]. In the context of one of the priorities of the scientific and technological development of the Russian Federation, the study and exploration of outer space, the media represent the most important tool for popularizing fundamental and applied space research and its impact on everyday life, thereby solving the highly relevant problem of updating the image of space and the important role of its further exploration in mass consciousness and society's representations about the present and the future [10]. Editorial staff of mass media are also interested in high-quality and comprehensive coverage of space topics, since space research, as well as life sciences, represent the most popular areas of scientific and technical information among the mass audience [14].

In addition, media are a force that is able to resist pseudoscience and false ideas about space [9, 15-18]. To date, features of the presence of space topics in general and scientific-technical information about space in the content of modern Russian media in particular seem to be insufficiently studied. This work is a step towards a comprehensive investigation of the quantitative and qualitative characteristics of space issues in modern media. An interdisciplinary approach to the study of the processes associated with the exploration of outer space and the impact of these processes on society and public consciousness seems to be extremely important in modern conditions. However, this direction is not sufficiently actualized in social sciences [11, 12]. Meanwhile, the attention of Western researchers to the topic of space in the context of media and mass culture has been growing [21-25].

\section{THE METHODOLOGY AND MAIN RESULTS OF THE STUDY}

The objective of this pilot study was to test the methodology for identifying the quantitative and qualitative presence of space exploration topics, scientific and technical achievements, and other areas related to space and covered in media discourse. The main methods in working with empirical material at different stages included content analysis, comparative analysis, descriptive method, continuous sampling method, and statistical and historical methods of linguistic analysis. The information retrieval system for monitoring and analysis of mass media Integrum and the word2vec algorithm complement traditional methods, making it possible to promptly analyze significant volumes of electronic texts for constructing models that account for the co-occurrence of words and to identify semantically close lexical units and whole groups. The main goal of the research presented in this paper was to obtain preliminary results and form a hypothesis for further primary research that would reveal stable trends in the presence of scientific and technical information about space in modern mass media.

The leading Russian federal socio-political newspapers Komsomolskaya Pravda, Rossiyskaya Gazeta, and Kommersant, as well as the Internet media Lenta.Ru and Gazeta.Ru, were selected as the object of the study. Their content was analyzed for the period from January to December 2020. Publications on the given topic were selected and analyzed using the information retrieval system for monitoring and analyzing the media Integrum, which indexes materials and contains archives of more than 12000 sources, as well as the word2vec algorithm based on artificial neural networks. The original methodology made it possible to determine the ratio of publications about space in the total amount of mass media reports and to identify key topical areas of space information agenda and features of its geography.

During the first research procedure, we formed a sample of 3964 publications (B1) containing keywords космо* (space, noun) or космическ* (space, adj.). This sample was correlated with the total number of publications in the selected media in the study period, 259227 publications (B0). It was concluded that publications were characterized by an extremely low level of the presence of information related to space topics, which accounted for only $1.5 \%$ of the total number of publications. At the same time, we should note a positive trend towards an increase in the share of publications on space from January to December 2020 (Fig. 1). The number of publications in December 2020, compared to January 2020, increased 1.7 times.

Comparative analysis of the number of publications with the keywords $\kappa о с м o^{*}$ (space, noun) or $\kappa o c-$ мическ* (space, adj.) in the studied media also yielded results: the total array of publications in the online media Lenta.Ru and Gazeta.Ru was on average 5.4 times higher than in the media that exist on two platforms, printed and digital. Of course, this is due to the difference in the models of the media and the information flow they produce, since they are primarily focused on news content and converged editions of these media operate $24 / 7$, that is, they produce content 24 hours a day, seven days a week. At the same time, the results of analyzing the share of publications about space in relation to the total array of publica- 
tions of each media showed that the share of the space agenda in newspapers is, on average, twice as large as in Internet media, which is shown in the diagram (Fig. 2).

The second research procedure consisted in quantitative analysis of the B1 sample in order to identify main thematic content areas that included information agenda related to space. To this end, thematic areas were identified, for which, in turn, keywords were selected for the most complete detection of these areas in the content of each media. As an example, the scientific and technological sphere was described by a set of keywords наук* (science), науч* (scientific), учен* (scientist), исслед* (research), техно ${ }^{*}$ (tech*), техни (tech*), and инноваи* (innovation). Then, using the Integrum system, the number of texts simultaneously containing the words космо* (space, noun) or космическ* (space, adj.) and at least one of the keywords that characterize the public sphere was determined. As a result, we obtained a list of the top seven thematic areas with the highest frequency of mentioning space (Fig. 3): scientific and technological area, $50 \%$; professional, $37 \%$; military, $34 \%$; environmental, $30 \%$; political, $26 \%$; economic, $23 \%$; cultural, $21 \%$.

This made it possible to draw a preliminary conclusion about the dominance of the scientific and technological context in the coverage of space-related topics in the socio-political segment of the media. Further, for quantitative analysis, a sample of 1987 publications (B2) was formed from texts of scientific and technological orientation. In turn, this showed that keywords that characterize research activities (наук* (science), науч* (scientific), учен* (scientist), исслед* (research)) are found in $76 \%$ of publications in the B2 sample, while keywords that characterize technical and technological topics (техно* (tech*), техни* (tech*), and инноваи* (innovation)) are found in $54 \%$ of publications. This result indicates that the media pay more attention to scientific and technical information about space in terms of science and research in this area and that their information agenda somewhat less promotes applied research results, description of practical application of scientific achievements, and the use of innovative technologies. This assumption will be verified during subsequent qualitative content analysis.

Further, the third procedure of approbation of the methodology for analyzing publications with reference to space by other characteristics was carried out. In particular, analysis of the B2 sample by characteristics related to the geography of space-related content showed that mentioning of the leading space powers is distributed as follows: Russian Federation, $75 \%$ of texts, United States, $46 \%$, followed by the European Union, $19 \%$, China, $18 \%$, and India, $3.2 \%$. India is so far insignificantly but still steadily present in the content of the media, which indicates the growth of its media presence in the field of space exploration.
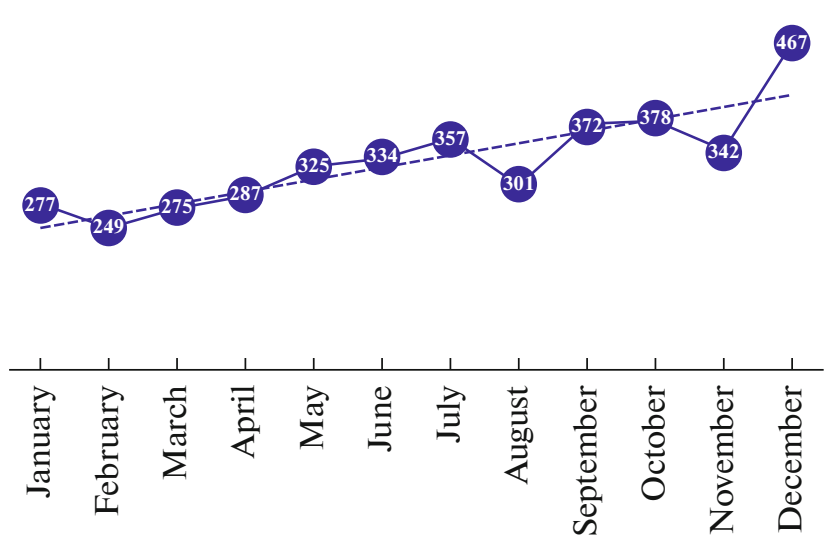

Fig. 1. The dynamics of the number of publications on space in 2020 .

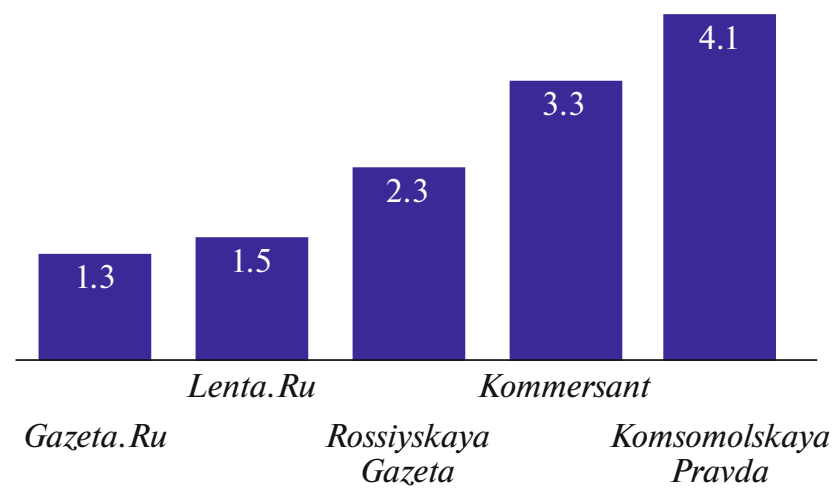

Fig. 2. The share of publications mentioning space in relation to the total number of publications by given media $(\%)$.

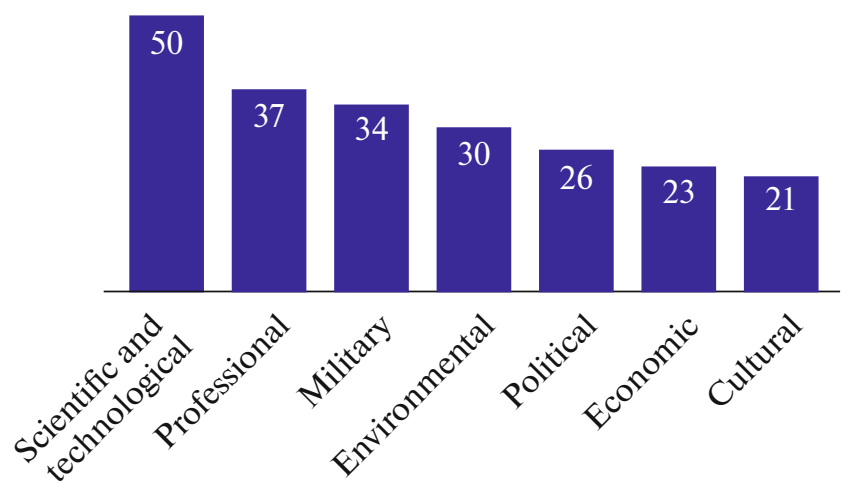

Fig. 3. The thematic areas of the space information agenda in the media (share of the sample B1, \%).

A preliminary assumption can be made that media serve as an indicator of current changes in the geography of the space information agenda: new players in this industry appear in the information field (primarily, China and India) [26-29]. This assumption will also be analyzed in more depth at further stages of the study. 
Table 1. Semantic analysis data: the semantic core of 30 nouns

\begin{tabular}{|c|c|}
\hline Category & Semantic core (30 nouns) \\
\hline Space & $\begin{array}{l}\text { сша (usa), ракета (rocket), система (system), космос (space), компания (company), корабль } \\
\text { (ship), проект (project), спутник (satellite), роскосмос (roskosmos), мкс (iss), программа } \\
\text { (program), президент (president), федерация (federation), глава (head), центр (center), } \\
\text { станция (station), новость (news), фильм (movie), аппарат (apparatus), космонавт (astro- } \\
\text { naut), полет (flight), ученый (scientist), союз (soyuz), запуск (launch), объект (object), } \\
\text { риа (ria), число (number), фото (photo), область (area), возможность (opportunity) }\end{array}$ \\
\hline $\begin{array}{l}\text { Space* } \\
\text { Lenta.ru }\end{array}$ & $\begin{array}{l}\text { сша (usa), фото (photo), ракета (rocket), роскосмос (roskosmos), компания (company), } \\
\text { корабль (ship), система (system), мкс (iss), новость (news), космос (space), спутник (satel- } \\
\text { lite), канал (channel), риа (ria), центр (center), проект (project), станция (station), союз } \\
\text { (soyuz), миллиард (billion), миллион (million), тысяча (thousand), программа (program), } \\
\text { рогозин (rogozin), звезда (star), ученый (scientist), рубль (ruble), процент (percent), доллар } \\
\text { (dollar), глава (head), луна (moon), космонавт (astronaut) }\end{array}$ \\
\hline $\begin{array}{l}\text { Space* } \\
\text { Gazeta.Ru }\end{array}$ & $\begin{array}{l}\text { сша (usa), ракета (rocket), система (system), корабль (ship), космос (space), спутник (satel- } \\
\text { lite), мкс (iss), компания (company), роскосмос (roskosmos), запуск (launch), полет (flight), } \\
\text { фильм (movie), программа (program), аппарат (apparatus), станция (station), проект (proj- } \\
\text { есt), глава (head), президент (president), новость (news), космонавт (astronaut), риа (ria), } \\
\text { газета (newspaper), орбита (orbit), союз (soyuz), оружие (arms), возможсность (opportu- } \\
\text { nity), китай (china), ученый (scientist), самолет (plane), луна (moon) }\end{array}$ \\
\hline $\begin{array}{l}\text { Space* } \\
\text { Kommersant }\end{array}$ & $\begin{array}{l}\text { рубль (ruble), президент (president), сиа (usa), проект (project), млрд (billion), владимир } \\
\text { (vladimir), господин (mister), компания (company), система (system), млн (million), тыс } \\
\text { (thousand), космос (space), число (number), путин (putin), суд (court), область (area), } \\
\text { сергей (sergei), связь (communication), развитие (development), глава (head), решение (solu- } \\
\text { tion), отношение (relation), рф (rf), правительство (government), рынок (market), центр } \\
\text { (center), александр (aleksandr), ситуация (situation), проблема (problem), государство } \\
\text { (state) }\end{array}$ \\
\hline $\begin{array}{l}\text { Space* } \\
\text { Komsomolskaya Pravda }\end{array}$ & $\begin{array}{l}\text { тысяча (thousand), рубль (ruble), фильм (movie), история (history), музей (museum), прези- } \\
\text { дент (president), герой (hero), александр (aleksandr), проект (project), космонавт (astro- } \\
\text { naut), корабль (ship), центр (center), улица (street), ученый (scientist), ракета (rocket), сайт } \\
\text { (site), сиа (usa), владимир (vladimir), ссср (ussr), станция (station), программа (program), } \\
\text { компания (company), коронавирус (coronavirus), миллион (million), роскосмос (roskosmos), } \\
\text { система (system), глава (head), цена (price), сергей (sergei), полет (flight) }\end{array}$ \\
\hline $\begin{array}{l}\text { Space* } \\
\text { Rossiyskaya Gazeta }\end{array}$ & $\begin{array}{l}\text { федерация (federation), статья (article), спутник (satellite), закон (law), пункт (point), } \\
\text { орган (body), система (system), проект (project), соответствие (compliance), программа } \\
\text { (program), область (area), право (law), объект (object), контроль (regulation), решение } \\
\text { (solution), деятельность (activity), президент (president), компания (company), развитие } \\
\text { (development), требование (requirement), число (number), перечень (list), информация } \\
\text { (information), тысяча (thousand), организация (organization), название (name), власть } \\
\text { (роwer), отношение (relation), порядок (order), правительство (government) }\end{array}$ \\
\hline
\end{tabular}

The next procedure is the approbation of the methodology for analyzing the lexical-semantic field of the sample B1 using the word2vec algorithm, which included only lexical units that denote the actants of situations. The core of the lexical system of the language is most often identified using the criterion of frequency. The calculation of the average frequency of occurrence of a word allows assigning the vocabulary whose frequency is higher than the average value to the core and the vocabulary whose frequency is below the average to the periphery. This procedure made it possible to identify a semantically similar context for the "space" category in the form of a semantic core (containing 30 nouns), which was formed automatically according to the principle of identifying words with the highest frequency. The occurrence of words was checked both separately for the "space" category and for each of the analyzed media (Table 1). Semantic analysis to a large extent confirmed the data obtained using the functionality of the Integrum system. 


\section{CONCLUSIONS}

The stage of research considered in this article allows us to draw the following preliminary conclusions.

(1) In general, the number of publications that mention space is extremely low in relation to the total number of publications of the considered media in aggregate: $1.5 \%$. At the same time, it was observed that the share of publications on space from January to December 2020 had an increasing trend, which can be regarded as a positive process, but its reasons require a deeper study at further stages.

(2) The results of the analysis of the number of publications about space in relation to the total array of publications of each media showed that the share of the space agenda in the socio-political publications Komsomolskaya Pravda, Rossiyskaya Gazeta, and Kommersant is on average twice as large as in the originally online media Lenta.Ru and Gazeta.Ru. It can be assumed that online media that operate $24 / 7$ and focus mainly on news formats pay much less attention to both the problem of space itself and its systematic analysis. Media that operate on printed and digital platforms, which have stronger traditions of professional and high-quality journalism and focus on a smaller but at the same time more educated and older audience (with Komsomolskaya Pravda being a definite exception), promote scientific and technical information about space more successfully.

(3) Analysis of the main thematic areas of the studied content showed the considerable prevalence of publications that cover the scientific and technological context of space-related topics. This indicates, first of all, a fairly high level of the audience's interest in information of scientific and technical nature and the potential need to develop this problem-thematic direction in current media discourse.

(4) We find that it is promising to continue research in the field of scientific and technical information about space through the comparative analysis of the core of the lexico-semantic field for the "space" category, which was identified in this study, with the semantic core of the period covering 1950-1961, which was characterized by intensive appending of the vocabulary due the start of the space age.

\section{FUNDING}

This study was supported by the Cosmos Interdisciplinary Scientific and Educational School of the Lomonosov Moscow State University.

\section{REFERENCES}

1. Vladimirova, T.N., Panferova, V.V., Smirnova, O.V., Svitich, L.G., and Shkondin, M.V., Journalism and the intellectual potential of society: Theoretical approaches to the system analysis of intellectual interaction in the media space, Vopr. Teorii Prakt. Zh., 2020, vol. 9, no. 1, pp. $90-105$.

https://doi.org/10.17150/2308-6203.2020.9(1).90-105

2. Anikina, M.E., Mediatization of science through the eyes of researchers, in Ostorozhno, lzhenauka! (Beware, Pseudoscience!), Vartanova, E.L., Ed., Moscow: Fak. Zh. Mosk. Gos. Univ. im. M.V. Lomonosova, 2015, no. 1, pp. 8-17.

3. Ursul, A.D., The information nature of culture, Sci. Tech. Inf. Process., 2018, vol. 45, no. 2, pp. 100-105. https://doi.org/10.3103/S0147688218020107

4. United Nations Institute for Disarmament Research, Conference Report, in Celebrating the Space Age: 50 Years of Space Technology, 40 Years of the Outer Space Treaty, Geneva: UNIDIR, 2007.

5. Ursul, A.D., The information aspect and temporal "code" of the inflationary phase of the evolution of the universe, Sci. Tech. Inf. Process., 2020, vol. 47, no. 2, pp. $81-88$.

https://doi.org/10.3103/S0147688220020033

6. Gerasimova, I.S., Foreign experience of visualization of scientific information in mass media, Mediaskop, 2016, no. 4. http://www.mediascope.ru/node/2185

7. Lazarevich, E.A., Popularization of science in Russia. Books, newspapers, and journals, Doctoral (Philol.) Dissertation, Moscow: Moscow State Univ., 1981.

8. Pankov, A.V., Popularization of science in periodicals (based on literary, social and political journals): Specificity of genres, Cand. Sci. (Philol.) Dissertation, Moscow: Moscow State Univ., 1973.

9. Vartanova, E.L., Dynamics of the general and the special: Modern theoretical approaches to the analysis of the russian media system, in Paralleli i meridiany mediaprostranstva (Parallels and Meridians of Media Space), Moscow: Fak. Zh. Mosk. Gos. Univ. im. M. V. Lomonosova, 2014, pp. 10-34.

10. Russian Space Industry: Expectations of Business and Society. Results of the Expert Research, Moscow: Tsentr Sots. Proekt. "Platforma," 2019, p. 60. https://pltf.ru/2019/11/27/span-style-font-size-80-kosmos-2-0-ozhidanija-obshhestva-ot-rossijskoj-kosmonavtiki-br-i-kosmonavtiki-ot-obshhestva-span

11. Latov, Yu.V. and Latova, N.V., Russian technological innovation in the national media (on the example of technoparks), Mir Ross., 2018, vol. 27, no. 4, pp. 141162.

12. Toganova, N.V., Tikhomirov, I.A., Kamenskaya, M.A., and Khramoin, I.V., Technologies and innovations in the Russian media, Innovatsii, 2016, no. 10, pp. 110118.

13. Syuntyurenko, O.V. and Gilyarevskii, R.S., Tasks of information support of innovative economic development and the role of engineering, Sci. Tech. Inf. Process., 2017, vol. 44, no. 2, pp. 107-118.

https://doi.org/10.3103/S0147688217020095

14. Emel'yanova, N.N. and Omelaenko, V.V., Russian science in the media context, Filos. Nauki Tekh., 2015, vol. 20 , no. 2, pp. 142-163.

15. Vartanova, E.L., On the importance of confronting pseudoscience, in Ostorozhno, lzhenauka! (Beware, Pseudoscience!), Vartanova, E.L., Ed., Moscow: Fak. 
Zh. Mosk. Gos. Univ. im. M.V. Lomonosova, 2015, no. 1, pp. 3-7.

16. Gurova, E.K., in Populyarizatsiya nauki: Zadachi, strategii, tekhnologii. Metodicheskoe posobie dlya zhurnalistov (Popularization of Science: Problems, Strategies, and Technologies. Methodological Guide for Journalists), Vartanova, E.L., Ed., Moscow: Fak. Zh. Mosk. Gos. Univ. im. M.V. Lomonosova, 2016.

17. Frolova, T.I., Nauka, SMI, obshchestvo: Kak dostich' vzaimoponimaniya. Ch. 1. Nauchnyi zhurnalist: Missiya, zadachi i kompetentsii. Metodicheskoe posobie po vyyavleniyu priznakov lzhenauki (Science, Mass Media, and Society: How to Achieve Mutual Understanding. Part 1. Science Journalist: Mission, Tasks, and Competencies: Methodological Guide for Identifying Signs of Pseudoscience), Vartanova, E.L., Ed., Moscow: Fak. Zh. Mosk. Gos. Univ. im. M.V. Lomonosova, 2015.

18. Frolova, T.I., Suvorova, S.P., Il'chenko, D.S., and Bugaeva, A.S., On the problem of the quality of popular science texts in the media, Vopr. Teor. Prakt. Zh., 2016, vol. 5, no. 2, pp. 233-246.

19. Pervushin, A.I., Krasnyi kosmos: Zvezdnye korabli Sovetskoi imperii (Red Space: Starships of the Soviet Empire), Moscow: Eksmo, 2007.

20. Petritskii, V.A., Kosmos. Chelovek. Kul'tura: Izbrannye Raboty (Space. Humans. Culture: Selected Works), St. Petersburg, 2011.

21. Benjamin, M., Rocket Dreams: How the Space Age Shaped Our Vision of a World Beyond, New York: Free Press, 2003.
22. Damjanov, K., The matter of media in outer space: Technologies of cosmobiopolitics, Int. J. Cult. Stud., 2015, vol. 33, no. 5, pp. 889-906. https://doi.org/10.1177/0263775815604920

23. Damjanov, K. and Crouch, D., Global media cultures among the stars: Formations of celebrity in outer space, Int. J. Cult. Stud., 2017, vol. 21, no. 5, pp. 553-568. https://doi.org/10.1177/1367877917705915

24. Launius, R.D., Heroes in a vacuum: The Apollo astronaut as cultural icon, Fla. Hist. Q., 2008, vol. 872, pp. 174-209.

25. Woods, A. and Hadfield, C., The superstar astronaut taking social media by storm, The Guardian, Feb. 23, 2013. https://www.theguardian.com/science/2013/ $\mathrm{feb} / 22 /$ chris-hadfield-canada-superstar-astronaut.

26. Imagining Outer Space: European Astroculture in the Twentieth Century, Geppert, A.C.T., Ed., Basingstoke: Palgrave Macmillan, 2012.

27. Harvey, B., Smid, H., and Pirard, Th., Emerging Space Powers: The New Space Programs of Asia, the Middle East and South America, Berlin: Springer, 2010.

28. Rao, U.R., India's Rise as a Space Power, New Delhi: Foundation Books, 2014.

29. WorldSpaceFlight, 2016. Astronaut/cosmonaut statistics. http://www.worldspaceflight.com/bios/stats1.php.

Translated by K. Lazarev 